\title{
Multiple Sclerosis: Discordance in Three Pairs of Dizygotic Twins
}

\author{
W. S. CENDROWSKI \\ From the Neurological Clinic of the Psychoneurological Institute in Pruszkow, Poland
}

The earliest records of concordance in multiple sclerosis go back to Goldflam in 1930 and Prussak in 1931 who noted it in twins of unrecorded zygosity, and to Legras in 1934 who gave the first account of its occurrence in uniovular twins. In the fairly extensive subsequent literature, Thums (1952), Curtius (1959), and Bammer, Schaltenbrand, and Solcher (1960) have stressed the significance of environmental factors, while Mackay and Myrianthopoulos (1966) have extended the scope of the studies on the genetic aspects of the affection by investigations on the relatives of probands; they too have stressed the interaction of exogenous and genetic influences in the development of the disorder. The present study briefly reports discordance in three pairs of dizygotic twins, and reviews the relevant literature.

\section{Present Study}

Three twin pairs were found in a series of 300 patients with multiple sclerosis interviewed during an epidemiological survey in western Poland (Cendrowski et al., 1968). In each pair of twins examination included establishing the type of zygosity by comparing physical characteristics and major blood groups.

Only one member of each of the three pairs showed in every case typical, remittent multiple sclerosis. One twin pair was unlike-sexed and multiple sclerosis affected the female twin. The two other pairs were all males. The twins were all dizygotic, judged by the differences in major blood groups and physical characteristics.

\section{Genetic Analysis}

All twin cases reported in the literature (Table I) since 1930, in whom probable and possible multiple sclerosis has been diagnosed, were included in the concordance study. In addition, five series of the relatives of non-twin propositi were analysed in order to compare prevalence rates between sibs, parents, and cousins.

Among 234 pairs reported in the literature only 35

Received May 7, 1968. were fully concordant; which does not support the theory that multiple sclerosis is a genetically determined disease. In a previous study 247 twin pairs were collected, but in 59 pairs zygosity was not recorded (Cendrowski, 1964). In the remaining series of 90 monozygotic and 85 dizygotic twin pairs pairwise concordance was observed only in 24 of the former, and in 11 of the latter pairs. Though this difference does not appear by chance alone and is statistically significant $\left(\chi^{2}=5 \cdot 14\right)$, it does not alter the conclusion about the low concordance rate in multiple sclerosis. When the formula of Allen, Harvald, and Shields (1967) was used to analyse pairwise concordance, the values were found to be $0 \cdot 153$ in monozygotic twins and 0.069 in dizygotic twins? Another point to be analysed is the correlation be tween the frequency rate of multiple sclerosis and the grade of kinship. Table II shows that the prevalence rate was highest in monozygotic twins, and slightly lower in dizygotic twins, and that multiple sclerosis was less prevalent in sibs, parents, and cousins. Such decreasing frequencies could be expected in a genetically determined disease. However, similar prevalence rates of multiple sclerosis in monozygotic and dizygotic twins (133.3 per 100,000 and 64.5 per 100,000 ) are not compatible with a genetic hypothesis. This obvious departure from otherwise decreasing frequencies can be explained only by the interaction of exogenous and genetic influences.

\section{Discussion}

The major role of exogenous factors in the development of multiple sclerosis seems to be indisputable in the light of low concordance rates in both identical or non-identical twin pairs, close prevalence rates among monozygotic and dizygotic twins, and the fact that the disease occurs about 6 times more often in dizygotic twins than in sibs.

Mackay and Myrianthopoulos (1966) thought that the influence of the genetic factor was particularly evident in so-called 'high risk families'. 
TABLE I

MONOZYGOTIC AND DIZYGOTIC TWINS WITH PROBABLE AND POSSIBLE MULTIPLE SCLEROSIS

\begin{tabular}{|c|c|c|c|c|c|c|c|c|c|}
\hline \multirow{2}{*}{ Reference } & \multicolumn{3}{|c|}{ Total No. of Pairs } & \multicolumn{3}{|c|}{ No. of Concordant Pairs } & \multicolumn{3}{|c|}{ No. of Discordant Pairs } \\
\hline & $\begin{array}{l}\text { Monozy- } \\
\text { gotic }\end{array}$ & Dizygotic & Both & $\begin{array}{l}\text { Monozy- } \\
\text { gotic }\end{array}$ & Dizygotic & Both & $\begin{array}{l}\text { Monozy- } \\
\text { gotic }\end{array}$ & Dizygotic & Both \\
\hline $\begin{array}{lc}\text { Goldfiam } & (1930) \\
\text { Prussak } & (1931) \\
\text { Koch }(1966) \text { and others } & (1934-1957) \\
\text { Thums } & (1952) \\
\text { Schwermann } & (1955) \\
\text { Hyllested } & (1956) \\
\text { Bammer et al. } & (1960) \\
\text { Schapira, Poskanzer, and Miller }(1963) \\
\text { Stazio et al. } & (1964) \\
\text { Markov and Leonovich } & (1964) \\
\text { Mackay and Myrianthopoulos }(1966) \\
\text { Cendrowski } & (1967) \\
\text { Holmes, Stubbs, and Larsen } & (1967)\end{array}$ & $\begin{array}{r}? \\
? \\
28 \\
13 \\
\\
6 \\
1 \\
1 \\
1 \\
39 \\
1\end{array}$ & $\begin{array}{c}6 \\
30 \\
8 \\
? \\
7 \\
2+? \\
\\
29 \\
3\end{array}$ & $\begin{array}{r}1 \\
1 \\
34 \\
43 \\
8 \\
55 \\
13 \\
5 \\
1 \\
1 \\
68 \\
3 \\
1\end{array}$ & $\begin{array}{r}12 \\
1 \\
1 \\
1 \\
9\end{array}$ & $\begin{array}{l}1 \\
1 \\
1 \\
? \\
2\end{array}$ & $\begin{array}{r}1 \\
1 \\
13 \\
2 \\
1 \\
2 \\
3 \\
0 \\
0 \\
1 \\
15 \\
0 \\
0\end{array}$ & $\begin{array}{r}16 \\
12 \\
\\
5 \\
1 \\
1 \\
0 \\
30 \\
1\end{array}$ & $\begin{array}{r}5 \\
29 \\
7 \\
? \\
5 \\
2+? \\
\\
23 \\
3\end{array}$ & $\begin{array}{r}21 \\
41 \\
7 \\
53 \\
10 \\
5 \\
1 \\
0 \\
53 \\
3 \\
1\end{array}$ \\
\hline Total & 90 & 85 & 234 & 24 & 11 & 39 & 66 & 74 & 195 \\
\hline
\end{tabular}

$\star$ (Cases quoted by Koch, 1966).

TABLE II

PREVALENCE OF MULTIPLE SCLEROSIS AMONG RELATIVES OF SINGLET AND TWIN PROPOSITI

\begin{tabular}{l|c|c|c|c|c}
\hline \multicolumn{1}{c|}{ Relatives } & $\begin{array}{c}\text { No. of } \\
\text { Propositi }\end{array}$ & $\begin{array}{c}\text { No. } \\
\text { Studied }\end{array}$ & $\begin{array}{c}\text { No. of } \\
\text { Secondary } \\
\text { Cases }\end{array}$ & $\begin{array}{l}\text { Prevalence } \\
\text { per 100,000 }\end{array}$ & $\begin{array}{c}\text { Percent. of } \\
\text { Secondary } \\
\text { Cases }\end{array}$ \\
\hline Monozygotic twins & 90 & 180 & 24 & $133 \cdot 3$ & $26 \cdot 6$ \\
Dizygotic twins & 85 & 170 & 11 & 64.5 & $12 \cdot 9$ \\
Sibst & 963 & 4022 & 44 & $10 \cdot 7$ & 4.5 \\
Parents & 2422 & 4822 & 12 & $2 \cdot 4$ & $0 \cdot 49$ \\
Cousins $\$$ & 2202 & 2900 & 7 & $2 \cdot 4$ & 0.31 \\
\hline
\end{tabular}

$\star$ Present series.

† Pratt, Compston, and McAlpine (1951), Allison and Millar (1954), and Sutherland (1956).

¥ Allison and Millar (1954), Müller (1953), and Sällstrem (1942).

$\$$ Mackay and Myrianthopoulos (1966).

This factor is not associated with major blood groups, haptoglobin types, $\gamma$-globulin level, skin reaction to encephalitogenic factor, or chromosome pattern (Cendrowski, 1967).

Recent cytochemical studies in certain autoimmune conditions argue in favour of the incorporation of viral RNA into host lymphocytes which became converted to an immunologically active status, as discussed by the author elsewhere (1968). It is possible that at this subcellular level genetic background may determine the immunological reactivity of competent lymphocytes.

\section{Summary}

Three pairs of dizygotic twins with discordance for multiple sclerosis are reported, and the literature since 1930 is analysed. The evidence suggests an interaction of major exogenous and to lesser degree genetic influences.

\section{REFERENCES}

Allen, G., Harvald, B., and Shields, J. (1967). Measures of twin concordance. Acta. genet. (Basel), 17, 475.

Allison, R. S., and Millar, J. H. D. (1954). Prevalence and familial incidence of disseminated sclerosis. Ulster med. $\mathcal{F} ., 23$, Suppl. 2, 1.
Bammer, H., Schaltenbrand, G., and Solcher, H. (1960). Zwillingsuntersuchungen bei Multipler Sklerose. Dtsch. Z. Nervenheilk., 181, 261.

Cendrowski, W. (1964). Twins with multiple sclerosis. (In Polish.) Pol. Tyg. lek., 19, 1883.

- (1967). Present status of investigations of familial multiple sclerosis. (In Polish.) Neurol. Neurochir. pol., 1, 711.

- (1968). Proliferation and immunologic activity of lymphocytes in multiple sclerosis. (In Polish.) Neurol. Neurochir. pol., $2,77$.

-, Wender, M., Dominik, W., Flejsierowicz, Z., Owsianowski, M., and Lech, L. (1968). Epidemiologic study of multiple sclerosis in Western Poland. Europ. Neurol. (Basel). In the press.

Curtius, F. (1959). Neuere Ergebnisse der erbbiologischen Multiple Sklerose-Forschung. Fortschr. Neurol. Psychiat., 27, 161.

Goldflam, S. (1930). Die diagnostische Bedeutung des rosslimoschen Reflexes bei Erkkrankungen des Zentralnervensystems. S. Karger, Berlin.

Holmes, F., Stubbs, D. W., and Larsen, W. E. (1967). Systemic lupus erythematosus and multiple sclerosis in identical twins. Arch. intern. Med., 119, 302.

Hyllested, K. (1956). Disseminated Sclerosis in Denmark. J. Jørgensen, Copenhagen.

Koch, G. (1966). Polysklerose. Humangenetik, Band V/1. Ed. by P. Becker. G. Thieme, Stuttgart.

Legras, A. (1934). Multiple Sclerose bij Tweelingen. Ned. T. Geneesk., 78, 174.

Mackay, R. P., and Myrianthopoulos, N. C. (1966). Multiple sclerosis in twins and their relatives. Arch. Neurol. (Chic.), 15, 449.

Markov, D., and Leonovich, A. L. (1964). K differentsialnoii diagnostike $i$ patogenezu semienich form rasseiannogo skleroza. Zh. Nevropat. Psikhiat., 64, 801. 
Müller R. (1953). Genetic aspects of multiple sclerosis. Arch. Neurol. Psychiat. (Chic.), 70, 733.

Pratt, R. T. C., Compston, N. D., and McAlpine, D. (1951). The familial incidence of disseminated sclerosis and its significance. Brain, 74, 191.

Prussak, L. (1931). Zur Frage des familiären Vorkommens der multiplen Sklerose. Z. ges. Neurol. Psychiat., 137, 415.

Sällstrem, T. (1942). Das Vorkommen und die Verbreitung der multiplen Sklerose in Schweden. Acta med. scand., Suppl. 137, 1.

Schapira, K., Poskanzer, D. C., and Miller, H. (1963). Familial and conjugal multiple sclerosis. Brain, 86, 315.
Schwermann, M. (1955). Beobachtungen an 8 Zwillingspaaren mit Polysklerose. Dissertation, Münster.

Stazio, A., Kurland, L. T. Bell, L. G., Saunders, M. G., and Rogot, E. (1964). Multiple sclerosis in Winnipeg, Manitoba: methodological considerations of epidemiologic survey. Ten year follow-up of a community wide study, and population re-survey. F. chron. Dis., 17, 415.

Sutherland, J. M. (1956). Observations on the prevalence of multiple sclerosis in Northern Scotland. Brain, 79, 635.

Thums, K. (1952). Eineiige Zwillinge mit konkordanter multipler Sklerose. Wien. Z. Nervenheilk., 4, 173. 